\title{
Detection of human papillomavirus DNA in anogenital condylomata in men using in situ DNA hybridisation applied to paraffin sections
}

\author{
STINA M SYRJÄNEN,* GEO von KROGH, † AND KARI J SYRJÄNEN \\ From the *Department of Oral Pathology and Radiology, University of Kuopio, Finland, the $\dagger$ Department of \\ Dermatology, Sodersjukhuset at Karolinska Institutet, Stockholm, Sweden, and the $\ddagger$ Laboratory of \\ Pathology and Cancer Research, Finnish Cancer Society, and Department of Pathology, University of \\ Kuopio, Kuopio, Finland
}

SUMMARY An in situ DNA hybridisation method was used to detect human papillomavirus (HPV) DNA (HPV types 6, 11, 16, and 18), and an immunoperoxidase (IP-PAP) method to detect HPV structural protein expression in paraffin sections of biopsy specimens from 133 men treated for penile (in 114 cases) and anal (in 19 cases) warts. The anatomical distribution on the penis of classic condyloma acuminatum and of papular and flat condylomata was practically identical. The gross appearance of the warts did not correlate with their morphology on light microscopy. The detection rate of dysplasia was very different in the three types of lesions $(25 \%$ in flat, $50 \%$ in acuminatum, and $75 \%$ in papular warts). Of 133 lesions, $59(44.4 \%)$ contained HPV antigens, their expression being inversely related to the grade of dysplasia; only $17 \%$ of HPV 16 lesions had detectable HPV antigen compared with $50 \%$ to $67 \%$ in lesions of the other three HPV types. HPV 16 and HPV 18 DNA were most commonly (11\%) detectable in Bowenoid lesions; however, most of the HPV 16 and 18 positive cases were found among the flat and acuminatum type of lesions. Though the overall detection rate of HPV DNA (76\%) did not correlate with the grade of dysplasia, a clear cut association of HPV 16 and HPV 18 with dysplastic lesions was found, none of the HPV 16 and $25 \%$ of the HPV 18 positive cases being devoid of concomitant dysplasia. The corresponding figures for HPV 6 and HPV 11 were $59.2 \%$ and $68.8 \%$, respectively. The implications of these findings are discussed in terms of epidemiologically established connections between penile and cervical cancer, with special emphasis on the high risk HPV types 16 and 18. The applicability of in situ DNA hybridisation as a powerful tool in the analysis of specific HPV DNA sequences in routinely processed biopsy specimens from these lesions is emphasised.

\section{Introduction}

Human papillomavirus (HPV) is currently accepted as the aetiological agent of venereal warts (condylomata acuminata), which affect the anogenital tract of both sexes. ${ }^{13}$ This is confirmed by detecting viral particles with electron microscopy, ${ }^{4}$ by identifying HPV structural proteins (viral capsid antigens) with immunohistochemical (IP-PAP) techniques, ${ }^{56}$ and by detecting HPV DNA with DNA hybridisation methods. $^{79}$

Address for reprints: Dr Stina M Syrjänen, Department of Oral Pathology, Institute of Dentistry, University of Kuopio, P O Box 6, SF-70211 Kuopio, Finland

Accepted for publication 26 May 1986
Condyloma is a sexually transmitted disease (STD $)^{3}$ that is currently becoming a serious clinical problem, especially in sexually promiscuous young women..$^{1-310}$ Strong evidence accumulated during the past 10 years suggests that HPV infections of the uterine cervix are associated with the development of premalignant and malignant lesions at this site. ${ }^{1-10}$ Similar data on penile warts have been provided by the reported association of different degrees of epithelial atypia with penile warts, as well as by the presence of HPV DNA of the "high risk" HPV types (16 and 18) in some penile lesions, especially those of bowenoid papulosis (BP). ${ }^{11-15}$ The malignant transformation of penile giant condylomata (Buschke-Löwenstein tumors) into squamous cell carcinoma has also been established. ${ }^{16} 17$ 
Further evidence to substantiate the concept of cervical carcinoma as an $\mathrm{STD}^{18}$ is provided by reports of an epidemiological association between carcinoma of the penis and that of the cervix. ${ }^{171920}$ Cervical cancer as a cause of death in 711 wives of men dying of penile cancer exceeded that expected. ${ }^{19}$ Such data suggest that some cases of penile and cervical cancer may have a common aetiological (possibly infectious) agent. ${ }^{171920}$ This hypothesis is strengthened by the discovery of HPV structural proteins and HPV 16 and 18 DNA in a substantial proportion of invasive cervical carcinomas, ${ }^{792122}$ in penile bowenoid papulosis lesions, ${ }^{791314}$ as well as in penile cancer (Villa LL, Lopes A, unpublished observation). A special feature of the high risk HPV types 16 and 18 is the potential for integration of their DNA into the host cell genome. ${ }^{21} 22$

Thus HPV typing by DNA hybridisation techniques has become essential in assessing the malignant potential of HPV lesions, including those of the penis. To accomplish this, methods should be developed that are applicable to routinely processed biopsy specimens. ${ }^{791723}$ In the present communication data are presented for the first time on penile warts analysed for HPV DNA using the in situ DNA hybridisation technique applied to routine paraffin embedded sections. ${ }^{23}$ Definite evidence is obtained of an association of HPV types 16 and, less often, HPV 18 with epithelial dysplasia in penile warts.

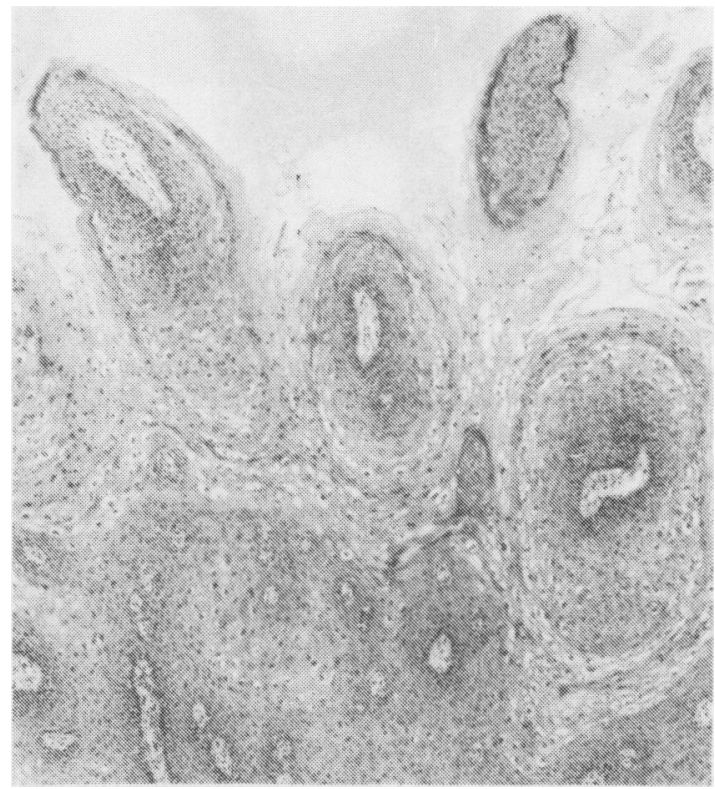

FIG 1 Extensive papillary condyloma of the glans, characterised by numerous papillary projections made up of koilocytotic cells, and covered by thick layers of superficial dyskeratotic cells. No signs of dysplasia found in this lesion. (Haematoxylin and eosin).
Patients, materials, and methods

The study published here consisted of 133 men who attended the outpatient department of dermatology, Södersjukhuset, Stockholm, Sweden during 1984; 114 men had penile and 19 men had anal warts. Patients were selected randomly from men who attended consecutively for the surgical treatment of previously untreated or recalcitrant warts. The mean age of the patients was 27.5 (SD 8.2) years. A careful clinical examination of each patient was undertaken by one of us (GvK), and the duration of the lesions before their removal was recorded. On macroscopic appearance the lesions were classified into one of three categories: condyloma acuminatum, papular condyloma, or flat condyloma.

Biopsy samples were immediately frozen and stored at $-70^{\circ} \mathrm{C}$ until being further processed. When required, the frozen biopsy sample was thawed, fixed in $10 \%$ neutral formalin, and processed for routine light microscopy. In sections stained with haematoxylin and eosin the light microscopic appearance of the lesions was classified according to the criteria outlined previously for flat condyloma, condyloma

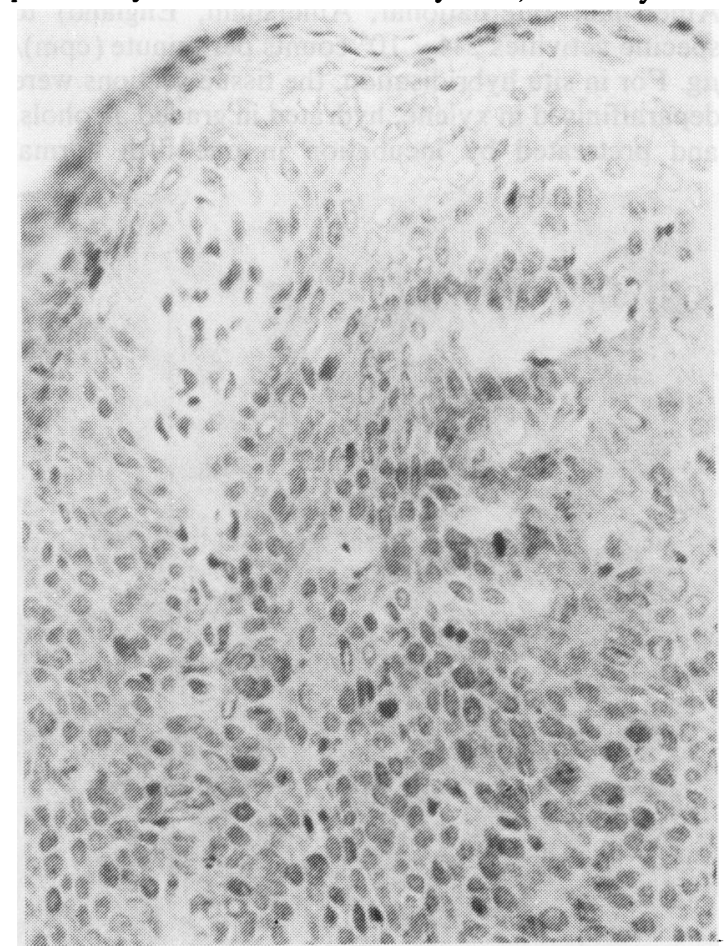

FIG 2 Medium power detail of another penile HPV lesion classified as bowenoid papulosis. (Lesion characterised by acanthotic squamous epithelium, which depicts pronounced dysplastic changes. Derangement of cell polarity, hyperchromatic stained nuclei, and numerous mitotic figures are seen.) (Haematoxylin and eosin.) 
acuminatum, and bowenoid papulosis. ${ }^{14} 24$ In all lesions, the degree of dysplasia was recorded as mild, moderate, or severe (figs 1 and 2). ${ }^{17}$

In routine paraffin sections, $\mathrm{HPV}$ structural proteins (group specific papillomavirus capsid antigens) were shown using a commercially available immunoperoxidase (IP-PAP) kit with the primary antiserum prepared against bovine papillomavirus virions (Dakopatts, Glostrup, Denmark) disrupted with sodium dodecyl sulphate (SDS) as detailed previously (fig 3). ${ }^{17}$

For HPV typing an in situ DNA hybridisation technique using probes of HPV DNA type $6,11,16$, and 18 was used on paraffin sections. The method used in our laboratory ${ }^{23}$ was a slight modification of that originally described by Gupta et al.$^{25}$ Briefly the paraffin embedded tissue was cut at 4-6 $\mu \mathrm{m}$ thicknesses. From a water bath containing $3 \%$ Elmer's glue as a bonding agent, the sections were mounted on poly-D-lysine coated slides. The pBR322 plasmid cloned HPV DNA probes were the same as those used for spot hybridisation. As an unrelated control, lambda phage DNA was used. The probe DNA was labelled by nick translation with $\left(\beta^{-35} \mathrm{~S}\right)$ dCTP $(1000 \mathrm{Ci} / \mathrm{mmol}$, Amersham International, Amersham, England) to specific activities $2-4 \times 10^{8}$ counts per minute $(\mathrm{cpm}) /$ $\mu \mathrm{g}$. For in situ hybridisation, the tissue sections were deparaffinised in xylene, hydrated in graded alcohols, and pretreated by incubation in one fifth normal

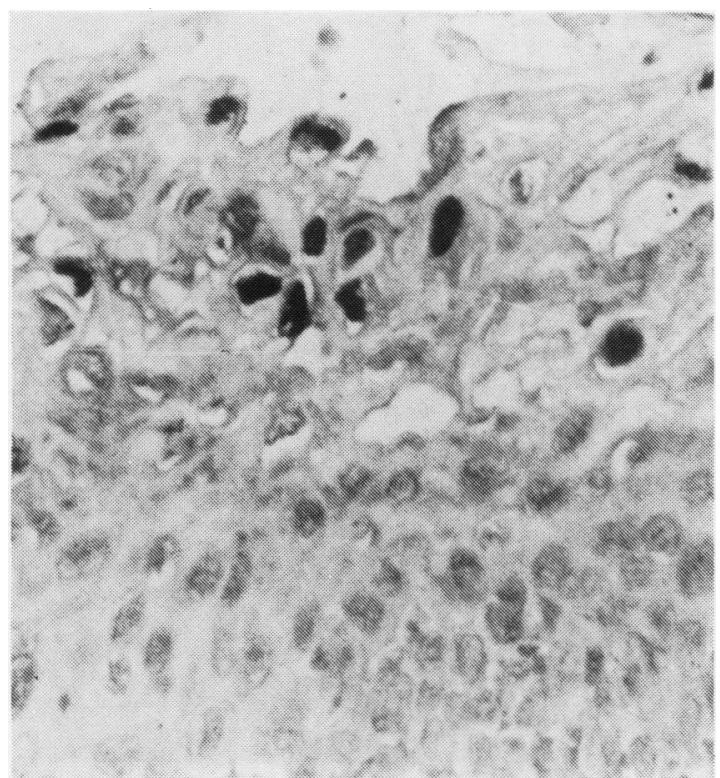

FIG 3 Flat penile squamous cell lesion stained by indirect immunoperoxidase technique to demonstrate HPV group specific capsid antigens. (Some of the superficially located koilocytes stained dark, indicating HPV structural proteins in their nuclei.) hydrogen chloride for 20 minutes, in $2 \times \operatorname{SSC}(0.3 \mathrm{~mol} / 1$ sodium chloride, $0.03 \mathrm{~mol} / 1$ sodium citrate) for six minutes, and in a $50 \mathrm{mg} / \mathrm{l}$ proteinase $K$ solution (Boehringer Mannheim) at $37^{\circ} \mathrm{C}$ for 15 minutes. The slides were put into phosphate buffered saline (PBS) containing $0 \cdot 2 \%$ glycine $(w / v)$ followed by PBS, dehydrated, and air dried.

The hybridisation mixture contained a final concentration of $50 \%$ formamide, $10 \% \mathrm{w} / \mathrm{v}$ dextran sulphate, $0.6 \mathrm{~mol} / 1$ sodium chloride, $0.01 \mathrm{~mol} / \mathrm{l}$ trometamol (TRIS) (pH 7.4), $0.5 \mathrm{mmol} / 1$ edetic acid, $1 \mathrm{~g} / 1$ benzenesulphonic acid, $0.02 \% \mathrm{w} / \mathrm{v}$ Ficoll, $0.02 \% \mathrm{w} / \mathrm{v}$ polyvinylpyrrolidone, $0.2 \mathrm{~g} / \mathrm{l}$ salmon sperm DNA, and $0.5 \mathrm{mmol} / 1$ dithiotreitol. The HPV DNA probe (HPV $6,11,16$, and 18) was added at a concentration of 2 $\mathrm{mg} / \mathrm{l}$ to the hybridisation mixture. This combination of the DNA probe and hybridisation mixture (probe cocktail) was then pipetted on to the specimens, covered with a double siliconised coverslip, and sealed

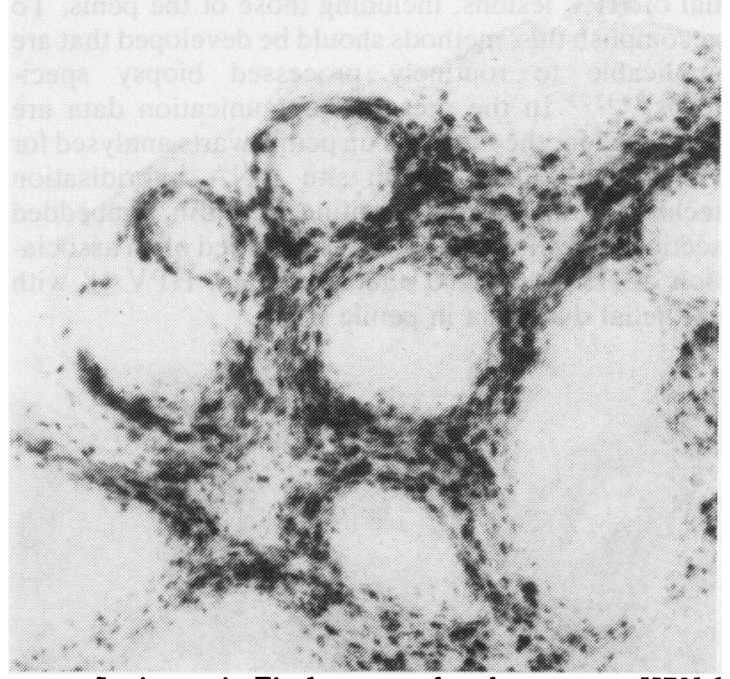

FIG 4 Lesion as in Fig 1 processed to demonstrate HPV 6 DNA by in situ DNA hybridisation technique under stringent conditions. (Intensely dark spots indicate HPV 11 DNA in the nuclei most epithelial cells.)

with rubber cement. The slides were placed in an incubator $\left(\right.$ at $\left.90^{\circ} \mathrm{C}\right)$ for six minutes and then put into an ice water solution. This served to denature both the tissue and the probe DNA. The specimens were hybridised for 50 hours at $42^{\circ} \mathrm{C}$ in a humidified chamber for conditions of high stringency $(\mathrm{Tm}-17)$ to detect specific HPV types. ${ }^{7-9}$

After hybridisation the coverslips were removed and the sections washed in four changes of $0.5 \times \mathrm{SSC}, 1$ $\mathrm{mmol} / \mathrm{l}$ edetic acid, and $1 \mathrm{mmol} / 1$ dithiotreitol (for five minutes in each), in two changes of $0.5 \times \mathrm{SSC}$, and 1 $\mathrm{mmol} / \mathrm{l}$ edetic acid (for five minutes in each) and 10 minutes in $50 \%$ formamide high salt solution at $55^{\circ} \mathrm{C}$, followed by four changes of $0.5 \times \mathrm{SSC}$ at $55^{\circ} \mathrm{C}$ (for five 
minutes), and once in $0.5 \times \mathrm{SSC}$ (for five minutes) at room temperature. The slides were dehydrated in graded ethanol ( $70 \%$ and $95 \%$ ) containing $0.3 \mathrm{~mol} / \mathrm{l}$ ammonium acetate, and allowed to air dry. The slides were then dipped in liquid photographic emulsion (Kodak Nuclear Tract NTB-3) diluted with an equal amount of $0.6 \mathrm{~mol} / \mathrm{l}$ ammonium acetate and allowed to dry overnight. They were then placed in light tight boxes for a four day exposure. Slides were developed with D-19 developer (Eastman Kodak), fixed in rapid fixer (Eastman Kodak), counterstained with Gill's haematoxylin, coverslipped, and mounted with Permount.

Positive results were indicated by a dense condensation of the black autoradiography grains superimposed on the nuclei of the epithelial cells (figs 4 and 5).

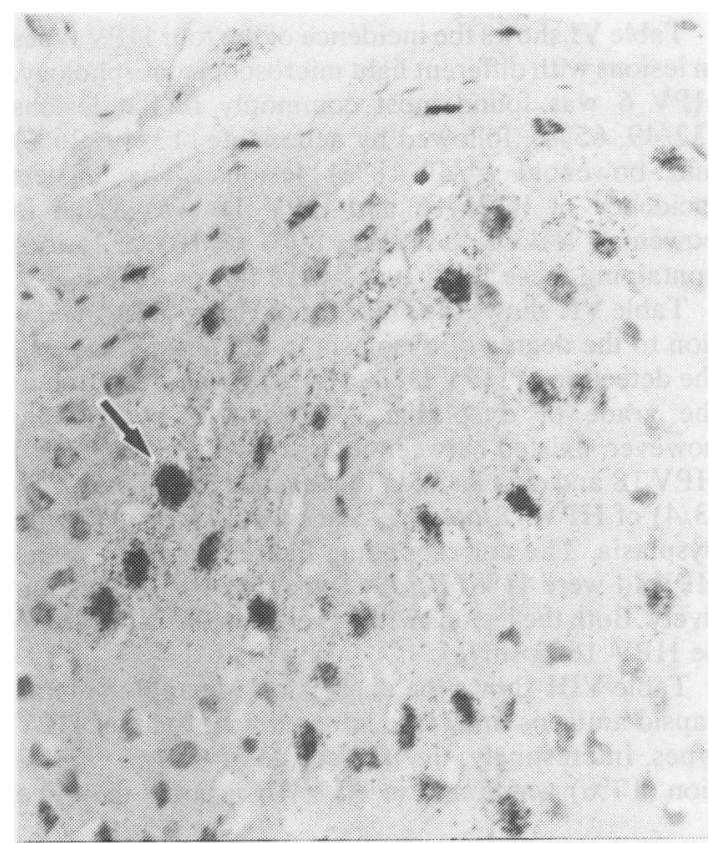

FIG 5 Medium power detail of superficial layers of a flat HPV lesion in situ hybridised with HPV 16 DNA under stringent conditions. (Black grains after autoradiography are superimposed on nuclei of koilocytotic cells (arrow) indicating $\mathrm{HPV} 16 \mathrm{DNA}$.)

\section{Results}

Table I enumerates the lesions characterised by macroscopic appearance and location. Condylomata acuminata were seen equally commonly at all anatomical sites. Most $71 \%(15 / 21)$ flat lesions were on the prepuce. Papular lesions were mostly on either the prepuce, the frenum, the penile shaft, or the anal area.

Table II summarises the light microscopic appearance of the lesions as well as the grade of associated dysplasia. The three types of lesions had noticeably different concomitant dysplasia. The bowenoid papulosis type of lesions were associated with dysplasia in $75 \%(18 / 24)$ of cases, compared with only $25 \%(16 / 63)$ of the flat condylomata. Only two lesions, both condylomata acuminata, showed severe dysplasia.

Table III shows the expression of HPV structural proteins in different types of lesions and related to

TABLE I Macroscopic appearance and location of anogenital lesions

\begin{tabular}{lcccc}
\hline & \multicolumn{4}{l}{ No (\%) with macroscopic appearance: } \\
\cline { 3 - 5 } Location & $\begin{array}{l}\text { No of } \\
\text { cases }\end{array}$ & \multicolumn{4}{l}{ Flat } & Acuminate & Papular \\
\hline Meatus & 14 & $1(7)$ & $11(79)$ & $2(14)$ \\
Glans & 5 & & $2(40)$ & $3(60)$ \\
Prepuce & 46 & $15(33)$ & $13(28)$ & $18(39)$ \\
Shaft & 16 & & $5(31)$ & $11(69)$ \\
Frenum & 20 & $3(15)$ & $6(30)$ & $11(55)$ \\
Coronal sulcus & 16 & $2(13)$ & $11(69)$ & $3(19)$ \\
Anus & 19 & & $7(37)$ & $12(63)$ \\
Total & $136^{*}$ & $21(15)$ & $55(40)$ & $60(44)$ \\
\hline
\end{tabular}

*Includes three cases with warts at more than one location.

TABLE II Characterisation of lesions according to microscopical appearance and grade of dysplasia

\begin{tabular}{lrrlll}
\hline & \multicolumn{5}{c}{$\begin{array}{l}\text { No (\%) with grade of associated } \\
\text { dysplasia: }\end{array}$} \\
\cline { 3 - 7 } $\begin{array}{l}\text { Microscopical } \\
\text { appearance }\end{array}$ & $\begin{array}{l}\text { No of } \\
\text { cases }\end{array}$ & None & Mild & Moderate & Severe \\
\hline Flat & 63 & $47(75)$ & $16(25)$ & & \\
Acuminate & 46 & $23(50)$ & $15(33)$ & $6(13)$ & $2(4)$ \\
Papular & 24 & $6(25)$ & $14(58)$ & $4(17)$ & \\
Total & 133 & $76(57)$ & $45(34)$ & $10(8)$ & $2(2)$ \\
\hline
\end{tabular}

TABLE III Expression of HPV structural proteins related to microscopical appearance and grade of dysplasia

\begin{tabular}{lcc}
\hline $\begin{array}{l}\text { Microscopical } \\
\text { appearance }\end{array}$ & $\begin{array}{l}\text { No of } \\
\text { cases }\end{array}$ & $\begin{array}{l}\text { No (\%) with } \\
\text { HPV antigens }\end{array}$ \\
\hline Flat & 63 & $38(60)$ \\
Acuminate & 46 & $17(37)^{*}$ \\
Papular & 24 & $4(17)$ \\
Grade of dysplasia & & \\
None & 76 & $41(54)$ \\
Mild & 45 & $15(33)^{* *}$ \\
Moderate & 10 & $3(30)$ \\
Severe & 2 & \\
Total & 133 & $59(44)$ \\
\hline
\end{tabular}

${ }^{*} \mathrm{p}=0.025 ; * * \mathrm{p}=0.05$ 
grade of dysplasia. As shown by the IP-PAP method, $59 / 133$ lesions (44\%) contained papillomavirus capsid antigens. Expression of the antigens was inversely related to the grade of dysplasia, and showed considerable variation in relation to the appearance of the lesions $(p<0.05$ between non-dysplastic and mildly dysplastic).

Table IV shows the distribution of the four HPV types in relation to the site of biopsy. Of the 108 lesions

TABLE IV Detection of HPV DNA in lesions at different locations

\begin{tabular}{llrrrrl}
\hline & & \multicolumn{5}{c}{ No (\%) with HPV type: } \\
\cline { 3 - 7 } Location & No with & HPV DNA & 6 & 11 & 16 & 18 \\
\hline Meatus & 11 & $7(64)$ & $3(27)$ & $1(9)$ & \\
Glans & 3 & $2(67)$ & & $1(33)$ & \\
Prepuce & 31 & $18(58)$ & $10(32)$ & $1(3)$ & $2(6)$ \\
Shaft & 8 & $4(50)$ & $3(38)$ & $1(13)$ & \\
Frenum & 14 & $9(64)$ & $4(29)$ & & $1(7)$ \\
Coronal sulcus & 12 & $2(17)$ & $8(67)$ & $2(17)$ & \\
Anus & 12 & $7(58)$ & $4(33)$ & & $1(8)$ \\
Total & $91^{*}$ & $49(54)$ & $32(35)$ & 6 & $(7)$ & $4(4)$ \\
\hline
\end{tabular}

*Includes nine cases with double infections: HPV 6 and 11 (seven cases), HPV 6 and 18 (one case), HPV 11 and 16 (one case).

TABLE V Detection of HPV DNA related to macroscopic appearance of lesions

\begin{tabular}{|c|c|c|c|c|c|}
\hline \multirow{2}{*}{$\begin{array}{l}\text { Macroscopic } \\
\text { appearance }\end{array}$} & \multirow{2}{*}{$\begin{array}{l}\text { No with } \\
\text { HPV DNA }\end{array}$} & \multicolumn{4}{|c|}{ No (\%) with HPV type: } \\
\hline & & 6 & 11 & 16 & 18 \\
\hline $\begin{array}{l}\text { Acuminate } \\
\text { Flat } \\
\text { Papular }\end{array}$ & $\begin{array}{l}50 \\
13 \\
28\end{array}$ & $\begin{array}{r}28(56) \\
3(23) \\
18(64)\end{array}$ & $\begin{array}{r}19(38) \\
7(54) \\
6(21)\end{array}$ & $\begin{array}{l}2(4) \\
4(14)\end{array}$ & $\begin{array}{l}1 \text { (2) } \\
3(23)\end{array}$ \\
\hline Total & $91^{*}$ & $49(54)$ & $32(35)$ & $6(7)$ & $4(4)$ \\
\hline
\end{tabular}

*Includes nine cases with double infections: HPV 6 and 11 (seven cases), HPV 6 and 18 (one case), HPV 11 and 16 (one case).

TABLE VI Detection of HPV DNA related to microscopical appearance of lesions

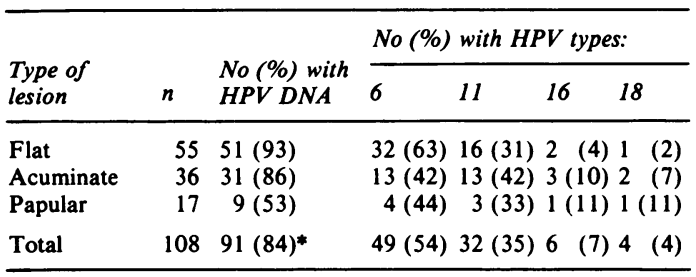

*Includes nine cases with double infections: HPV 6 and 11 (seven cases), HPV 6 and 18 (one case), HPV 11 and 16 (one case). analysed by in situ DNA hybridisation, 91 (84\%) contained at least one HPV DNA, HPV 6 being the most common type (54\% (49/91)) of those with HPV DNA. The distribution of HPV 6 lesions seemed to be relatively even except on the coronal sulcus, where HPV 11 was most common. Noteworthy was the finding of double infections with HPV 6 and 11,6 and 18, and 11 and 16 in nine warts.

Table $\mathrm{V}$ summarises the detection rate of the four HPV types in relation to their macroscopic appearance. HPV 6 DNA was found less often in flat lesions than in acuminate and papular condylomata $(p<0.05$ and $p<0.025$, respectively). HPV 11 occurred in all types of warts, whereas most of the HPV 16 infected lesions were of the papular type. HPV 18 was present in one acuminate and in three flat warts.

Table VI shows the incidence of the four HPV types in lesions with different light microscopic morphology. HPV 6 was found most commonly in flat lesions $(32 / 49,65 \%)$, followed by acuminate $(13 / 49,26 \%)$ and bowenoid $(4 / 49,8 \%)$ lesions. The highest incidence of HPV 16 and HPV 18 was found in bowenoid lesions; however, $80 \%(8 / 10)$ of lesions containing these HPV types were flat or acuminate.

Table VII shows the presence of HPV DNA in relation to the degree of dysplasia in the lesions. Overall the detection of HPV DNA (84\%) bore no relation to the grade of dysplasia. A clear cut association, however, existed between infection with HPV 16 and HPV 18 and dysplasia, in that each HPV 16 and $75 \%$ $(3 / 4)$ of HPV 18 positive cases were associated with dysplasia. The corresponding figures for HPV 6 and HPV 11 were $41 \%(20 / 49)$ and $31 \%(10 / 32)$, respectively. Both the lesions with severe dysplasia proved to be HPV 16 positive.

Table VIII shows the expression of papillomavirus capsid antigens in lesions infected with the four HPV types. Interestingly, the lowest rate of antigen expression $(17 \%)$ was found in HPV 16 lesions, the three

TABLE VII Detection of HPV DNA related to grade of dysplasia

\begin{tabular}{|c|c|c|c|c|c|c|}
\hline \multirow{2}{*}{$\begin{array}{l}\text { Grade of } \\
\text { dysplasia }\end{array}$} & \multirow[b]{2}{*}{$n$} & \multirow{2}{*}{$\begin{array}{l}\text { No (\%) with } \\
\text { HPV DNA }\end{array}$} & \multicolumn{4}{|c|}{ No (\%) with HPV type: } \\
\hline & & & 6 & 11 & 16 & 18 \\
\hline None & 62 & $52 \quad(84)$ & $29(56)$ & $22(42)$ & & 1 (2) \\
\hline Mild & 36 & $30 \quad(83)$ & 17 (57) & $8(27)$ & (10) & $2(7)$ \\
\hline Moderate & 8 & $7(88)$ & $3(43)$ & $2(29)$ & 1 (14) & 1 (14) \\
\hline Severe & 2 & $2(100)$ & & & $2(100)$ & \\
\hline Total & 108 & $91(84)^{*}$ & $49(54)$ & $32(35)$ & (7) & $4(4)$ \\
\hline
\end{tabular}

*Includes nine cases with double infections: HPV 6 and 11 (seven cases), HPV 6 and 18 (one case), HPV 11 and 16 (one case). 
TABLE VIII Detection of HPV DNA related to expression of HPV structural proteins

\begin{tabular}{lll}
\hline $\begin{array}{l}\text { Type of } \\
\text { HPV DNA }\end{array}$ & $\begin{array}{l}\text { No of } \\
\text { cases }\end{array}$ & $\begin{array}{l}\text { No (\%) with } \\
\text { HPV antigens }\end{array}$ \\
\hline HPV 6 & 49 & $33(67)$ \\
HPV 11 & 32 & $18(56)$ \\
HPV 16 & 6 & $1(17)$ \\
HPV 18 & 4 & $2(50)$ \\
Total & 91 & $54(59)$ \\
\hline
\end{tabular}

others being similar $(50 \%$ to $67 \%)$ in their HPV antigen expression rate $(p<0.025$ between cases with HPV 6 and $11 v$ HPV 16).

\section{Discussion}

Penile condylomata are usually recorded in patients aged 20-25 in countries with a high incidence of penile cancer and in patients aged 26-30 in European countries. ${ }^{17}$ The mean age of the patients in the present study was 27.5 years (SD 8.2). Though penile carcinoma is a rare disease in most western countries, it is relatively common in Thailand, India, China, Puerto Rico, and in certain parts of Africa, such as Kenya, Tanzania, and Uganda. Penile cancer is most prevalent in patients aged 50 in Uganda, compared with those aged 60 in Europe. ${ }^{17}$ Apparently there is an interval of 30 years between the onset of penile condylomata and the subsequent development of penile cancer. In areas with a high prevalence of penile carcinoma, such as Uganda, however, another age peak of penile condylomas exists, which preceds the age peak of penile carcinoma by only a few years. ${ }^{17}$ Because such a peak is not observed in Europe, this has been interpreted as representing the immediate precursor of penile carcinomas. ${ }^{17}$

Recent published reports have focused on the epidemiological association between penile carcinoma and carcinoma of the uterine cervix. ${ }^{17} 1920$ In a study of 889 men with penile cancer in Puerto Rico, eight of their wives developed cervical cancer compared with none of the control women. ${ }^{28}$ Subsequent reports have generally confirmed these findings, ${ }^{1920}$ which suggests that some cases of penile and cervical cancer may have a common aetiological (viral) agent. The hypothesis has gained support by the discovery of HPV structural proteins in cervical intraepithelial neoplasia (CIN) lesions, as well as HPV 16 and 18 DNA in invasive cervical carcinomas, ${ }^{792122}$ in penile bowenoid papulosis, ${ }^{79131424}$ and in penile cancer (Villa LL, Lopes A, unpublished observation). In addition, the number of reports of the malignant transformation of penile condylomata has rapidly expanded. ${ }^{16} 17$ Furthermore, the STD nature of the newly described flat and endophytic HPV lesions of the uterine cervix has been firmly established. ${ }^{1726}$ Thus the well known factors that increase the risk of cervical cancer evidently also correlate with the presence of cervical HPV infections. ${ }^{1726}$ This is further substantiated by the observations on the natural history of cervical HPV lesions, which frequently coexist with classical CIN and may progress to carcinoma in situ (CIS) and to invasive cancer. ${ }^{26}$ All these data strongly suggest that sexually transmitted HPV infection may play an important part in the aetiology of both cervical and penile squamous cell cancer.

Studies of cervical HPV infections indicate that HPV types 16 and 18 behave more aggressively than others - for example, they are more frequently associated with dysplasia and malignant transformation. ${ }^{1}{ }^{172628}$ The potential for integration of HPV DNA into the host cell genome has been suggested as a special feature of these "high risk" HPV types, and cervical lesions induced by HPV 16 and 18 seem to progress more readily than those caused by HPV 6 and 11.2628 These observations clearly emphasise the necessity of HPV typing to assess the malignant potential of all HPV lesions, including those of the penis. ${ }^{11-}$ ${ }_{1524}$ Such an analysis was made for HPV 6, 11, 16, and 18 DNA in the present series of 114 men with penile and 19 with anal condylomas using the in situ DNA hybridisation technique applied to routinely processed paraffin embedded sections.

In the present study, the condylomata were equally distributed at the various anatomical sites of the penis, the prepuce being the most common site. When classified according to gross appearance, papular lesions outnumbered condylomata acuminata and flat warts (table I). The correlation between macroscopic appearance and light microscopical morphology was poor (table II), which agrees with a recent report indicating that the histological pattern of clinically different penile condyloma types is often similar. Thus light microscopy seems to be of limited value in the classification of these lesions. ${ }^{24}$ Undoubtedly, much of this discrepancy is due to a variable gross appearance of bowenoid papulosis, which is known to present with several clinical patterns, such as erythematous macules, reddish or pigmented papules, or leukoplakia like lesions. ${ }^{11-15}$

Despite their light microscopical features in common, the three types of lesions had noticeably different prevalence of associated dysplasia (table II). Seventy five per cent $(18 / 24)$ of the bowenoid papulosis lesions were associated with dysplasia compared with $50 \%(23 / 46)$ of the acuminate and $25 \%(16 / 63)$ of flat condylomas. This finding agrees with current concepts on bowenoid papulosis as a potentially precancerous lesion of the penis. ${ }^{11-15}$ As the name implies, the bowenoid papulosis lesions resemble Bowen's disease on light microscopy. ${ }^{11-15}$ The HPV 
aetiology of bowenoid papulosis was originally suggested by the discovery of HPV particles and HPV antigens in these lesions, ${ }^{13}$ and has been confirmed subsequently by the repeated finding of HPV DNA in the lesions..$^{14} 15$ In a recent study, HPV type 16 DNA was found in $8 / 10$ biopsy specimens of penile bowenoid papulosis lesions, two of which also contained sequences of HPV $18 .{ }^{15}$ In another study, HPV 16 DNA was disclosed in all 12 cases. ${ }^{14}$ In the present study, HPV structural proteins were shown by the IP-PAP method in only $17 \%$ (4) of the 24 bowenoid papulosis lesions (table III), the antigen expression being inversely related to the grade of dysplasia. This is also true for cervical HPV lesions. ${ }^{17}$

In agreement with these reports, nine of the 17 cases of bowenoid papulosis in the present series contained DNA of at least one HPV type, of which HPV 16 and HPV 18 each comprised $11 \%(1 / 9)$ (table VI). The differences in the prevalence of HPV 16 DNA in previous publications ${ }^{1415}$ compared with the present one are most probably explained by a different selection of patients, in that our material did not include any case of severely atypical (in situ cancer) lesions of bowenoid papulois (table II). Though the overall detection of HPV DNA (84\%) did not bear any relation to the grade of dysplasia, HPV 16 was more often found in tissue that showed dysplasia (table VII). Furthermore, each of the HPV 16 and $75 \%(3 / 4)$ of the HPV 18 positive lesions were associated with dysplasia, the corresponding figures for HPV 6 and HPV 11 being $40 \%(20 / 49)$ and $31 \%(10 / 42)$. In a recent comparable study of 59 cases, ${ }^{24} 63 \%$ of condylomata acuminata contained HPV 6 DNA, 22\% HPV 11, but none contained HPV 16. In flat condyloma like lesions, the corresponding figures were $44 \%, 11 \%$, and $33 \%$, and in pigmented papule lesions $0 \%, 25 \%$, and $25 \%$, respectively. ${ }^{24}$ Though there are some differences, these figures parallel closely those of the present study (tables V and VI).

Reliable data from prospective studies on the natural history of penile HPV lesions are not yet available. Attempts to detect HPV infections of the penis and in the urethra of male consorts of women with cervical HPV infections are under way, and the role of the man as the carrier of HPV needs further assessment. ${ }^{1729}$ The clinical course of penile warts possibly varies; some seem to regress spontaneously, though most seem to persist for a considerable time, and some (possibly induced by HPV 16 or HPV 18) may progress to malignancy. ${ }^{11-17}$ Of special interest in this respect are the present observations that the expression of papillomavirus capsid antigens was extremely low $(17 \%, 1 / 6)$ in HPV 16 lesions (table VIII)compared with that $(50 \%(2 / 4)$ to $67 \%(33 / 49))$ in lesions due to the three other HPV types. This suggests a non-productive (transforming) infection by HPV 16, probably conditioned by the integration in the host cell genome of this HPV type. ${ }^{21} 22$

In conclusion, the present results show that neither the location, macroscopic appearance, nor light microscopical morphology of penile condylomata is of any value in predicting infection by the high risk HPV types 16 and 18 , which seem to be intimately associated with the presence of dysplasia in these lesions. This emphasises the role of the DNA hybridisation method in assessing infection as either a low risk or a high risk type. Because of its applicability in routine paraffin sections, the potential of the in situ DNA hybridisation with non-isotope-labelled probes should be emphasised for routine screening purposes.

This work was supported by research grants from the Medical Research Council of the Academy of Finland and from the Finnish Cancer Society. The skilful technical help of Mrs Heli Eskelinen, Miss Helena Kemilainen, Mrs Maritta Lipponen, and Miss Ritva Savoläinen is gratefully acknowledged. The authors extend their special thanks to Dr Lutz Gissmann, Deutsches Krebsforschungszentrum, Heidelberg, West Germany, for providing the HPV DNA probes.

\section{References}

1. Syrjänen KJ. Current concepts on human papillomavirus (HPV) infections in the genital tract and their relationship to intraepithelial neoplasia and squamous cell carcinoma. Obstet Gynecol Surv 1984;39:252-65.

2. Okagaki T. Female genital tumors associated with human papillomavirus infection, and the concept of genital neoplasmpapilloma syndrome (GENPS). Pathol Annu 1984;19:3162.

3. Oriel JD. Genital warts. Sex Transm Dis 1981;8:326-9.

4. Hills E, Laverty CR. Electron microscopic detection of papilloma virus particles in selected koilocytotic cells in routine cervical smears. Acta Cytol (Baltimore) 1979;23:53-6.

5. Woodruff JD, Braun L, Cavalieri R, Gupta P, Pass F, Shah KV. Immunologic identification of papillomavirus antigen in condyloma tissues from the female genital tract. Obstet Gynecol 1980;56:727-32.

6. Syrjänen KJ, Pyrhönen S. Demonstration of human papilloma virus (HPV) antigens in a case of urethral condyloma. Scand J Urol Nephrol 1983;17:267-70.

7. Gissmann L. Papillomaviruses and their association with cancer in animals and in man. Cancer Surv 1984;3:161-81.

8. Gissmann L, Boshart M, Dürst M, Ikenberg H, Wagner D, zur Hausen $\mathrm{H}$. Presence of human papillomavirus in genital tumors. J Invest Dermatol 1984;83:26s-28s.

9. Pfister H. Biology and biochemistry of papillomaviruses. Rev Physiol Biochem Pharmacol 1984;99:112-81.

10. Syrjänen $\mathrm{K}$, Väyrynen $\mathrm{M}$, Castrén $\mathrm{O}$, et al. Sexual behaviour of woemn with human papillomavirus (HPV) lesions of the uterine cervix. British Journal of Venereal Diseases 1984;60:243-8.

11. Wade TR, Kopf AW, Ackerman AB. Bowenoid papulosis of the genitalia. Arch Dermatol 1979;115:306-8.

12. Steffen C. Concurrence of condylomata acuminata and bowenoid papulosis: confirmation of the hypothesis that they are related conditions. Am J Dermatopathol 1982;4:5-8.

13. Guillet GY, Braun L, Masse R, Aftimos J, Geniaux M, Texier L. Bowenoid papulosis. Demonstration of human papillomavirus (HPV) with anti-HPV immune serum. Arch Dermatol 1984;120:514-6. 
14. Gross G, Hagedorn M, Ikenberg H, et al. Bowenoid papulosis. Presence of human papillomavirus (HPV) structural antigens and of HPV 16-related DNA sequences. Arch Dermatol 1985;121:858-63.

15. Ikenberg H, Gissmann L, Gross G, Grussendorf-Conen E-I, zur Hausen $\mathrm{H}$. Human papillomavirus type 16-related DNA in genital Bowen's disease and in Bowenoid papulosis. Int $J$ Cancer 1983;32:563-5.

16. Boxer RJ, Skinner DG. Condylomata acuminata and squamous cell carcinoma. Urology 1977;9:72-8.

17. Syrjänen KJ. Human papillomavirus (HPV) infections of the female genital tract and their associations with intraepithelial neoplasia and squamous cell carcinoma. Pathol Annu 1986;21:53-89.

18. Singer A, Reid BL, Coppleson M. A hypothesis: the role of a high-risk male in the etiology of cervical carcinoma. Am J Obstet Gynecol 1976;126:110-5.

19. Graham S, Priore R, Graham M, Browne R, Burnett W, West D. Genital cancer in wives of penile cancer patients. Cancer 1979;44:1970-4.

20. Cocks PS, Peel KR, Cartwright RA, Adib R. Carcinoma of penis and cervix. Lancet 1980;ii:855-6.

21. Dürst $\mathbf{M}$, Gissmann L, Ikenberg $\mathbf{H}$, zur Hausen $\mathbf{H}$. A papillomavirus DNA from a cervical carcinoma and its prevalence in cancer biopsy samples from different geographic regions. Proc Natl Acad Sci USA 1983;80:3812-5.

22. Boshart M, Gissmann L, Ikenberg H, Kleinheinz A, Scheurlen W, zur Hausen H. A new type of papillomavirus DNA, its presence in genital cancer biopsies and in cell lines derived from cervical cancer. EMBO J 1984;3:1151-7.

23. Syrjänen $S$, Syrjänen $\mathrm{K}$, Mäntyjärvi $\mathrm{R}$, et al. Detection of human papillomavirus (HPV) DNA sequences by in situ DNA hybridization in paraffin-embedded cervical biopsies of prospectively followed-up women. Arch Gynecol 1986;239:3948.

24. Gross G, Ikenberg H, Gissmann L, Hagedorn M. Papillomavirus infection of the anogenital region: correlation between histology, clinical picture, and virus type. Proposal of a new nomenclature. J Invest Dermatol 1985;85:147-52.

25. Gupta JW, Gendelman HE, Naghashfar Z, et al. Specific identification of human papillomavirus type in cervical smears and paraffin sections by in situ hybridization with radioactive probes: a preliminary communication. Int J Gynecol Pathol 1985;4:211-8.

26. Syrjänen K, Väyrynen M, Saarikoski S, et al. Natural history of cervical human papillomavirus (HPV) infections based on prospective follow-up. Br J Obstet Gynaecol 1985;92:1086-92.

27. Martinez I. Relationship of squamous cell carcinoma of the cervix uteri to squamous cell carcinoma of the penis among Puerto Rican women married to men with penile carcinoma. Cancer 1969;24:777-80.

28. Syrjänen $\mathrm{K}$, de Villiers $\mathrm{E}-\mathrm{M}$, Väyrynen $\mathbf{M}$, et al. Cervical papillomavirus infection progressing to invasive cancer in less than three years. Lancet 1985 ; i:510-1.

29. Levine RU, Crum CP, Herman E, Silvers D, Ferenczy A, Richart RM. Cervical papillomavirus infection and intraepithelial neoplasia: a study of male sexual partners. Obstet Gynecol 1984;64:16-20. 